\title{
Mental health and gender: nursing home care or careless?
}

\begin{abstract}
An alternative to live to old age in our culture is the nursing home. This research aims to investigate, through a mini literature review, what gender studies have contributed to the understanding of the men and women lives in a nursing home. However, the results demonstrated that are gender differences in how to deal with these experiences, as well as its impact on mental health.
\end{abstract}

Keywords: old age; gender; totalitarian institution
Volume 3 Issue 4 - 2018

\author{
Guilherme Henderson,' Valeska Zanello, ${ }^{2}$ \\ Livia Campos e Silva ${ }^{3}$ \\ 'Professor of the Centro Universitário de Brasília, Doctorate \\ in Clinical Psychology and Culture in Universidade de Brasília, \\ Brazil \\ ${ }^{2}$ Professor of the Department of Clinical Psychology of the \\ Universidade de Brasília, Brazil \\ ${ }^{3}$ Master in Clinical Psychology and Culture of the Universidade \\ de Brasília, Brazil
}

Correspondence: Guilherme Henderson, Professor of the Centro Universitário de Brasília, Doctorate in Clinical Psychology and Culture in Universidade de Brasília, Brazil, Email guilhermefh@gmail.com

Received: April 02, 2018| Published: August 13, 2018

\section{Introduction}

In general, on the matter of aging studies, three points of view stand out. The Biological one, which establishes old age as the process that starts once some defects are introduced in the good operation of the body, such as reproduction, or at the beginning of its degenaration state. The psycho-developmental view, where ging would be understood as a phase of development, therefore a period of life with behavioral and emotional issues parameters "normal" expected for this stage. The social point of view, under which old age would be understood from the various contexts-social, cultural and political. But historically, between these perspectives the idea of old age while organic degeneration is what acquired privileged status on the imagination.

Groisman ${ }^{1}$ States that one of the criteria that defines what it means to be "old" in our days is the chronological age. However, the arbitrariness that resides in this criterion is easily shown when we found two people with the same age, or in a "phase" of development, in degrees of aging completely dissonant (Hawk \& Aguilar, 2010). The organic body's degree of degeneration is another criterion found, apparently less arbitrary, that seeks to determine the age (and not to old age). This criterion also ignores the possibilities of aging, if restricting the indicial logic that is in the body signs of a malfunction.

This "degree" would determine what is the old age. The level of degeneration that organism's body features, is found in our society especially by doctor's look. Even so as in Foucault's alert, ${ }^{2}$ before being an empirical finding neutral on the body, the medical discourse about this "degeneration" creates the very association between old age and physical decline, between old age and disease. Laslett ${ }^{3}$ States that the idea of degeneration is the main medical metaphor of old age's body, making this the own knowledge about old age: Geriatrics, gerontology.

This metaphor has seeped increasingly in the social field and is still alive today. Nevertheless, the geriatrics and Gerontology seem to be at all times seeking ways to undo this old-age Associationdegeneration. ${ }^{1}$ When, for example, credit to old age a "natural" phase of life, or the linking to "positive practices "that is, a series of practices of prevention, as health care, body's rejuvenation and development of an active social life, clubs, universities. These are activities that built a new-age design known as the "Third Age" (Matthews, 2011).

Media disclosures of a type known considered healthy aging seniors, according to Groisman, ${ }^{4}$ is extremely vicious. Because it hides brazilian social reality: the aging as "healthy" is available for a minority class and the asylum model is far from being abandoned. In Brazil, geriatric institutions may be public or private and there are, on average, 3,549 identified institutions nationwide. ${ }^{5}$ Although it is possible to point out changes in this type of institution, ${ }^{6}$ by evualating that is possible subjective well-being of seniors living in long-stay Institutions - as they are called by the Brazilian of Geriatrics and Gerontology Society, the majority of authors, ${ }^{7,8}$ persists in denouncing insecurity and problems of this type of asylum institution, such as: the lack of recreational activities with an exchanging environment, or a listening space for misery and for the expression of singularities. Such precarity reveals some similarities between the geriatric institution and the totalitarian institution.

Even if it's not an asylum, a prison or a convent, the geriatric institution of asylum model has its operation's mode based on repressive postures, and hierarchical controllers, typical of what Goffman ${ }^{9}$ called total institutions. These organizations act in such a way as to make it impossible for individuals to exercise a minimum of selfness, being obliged to follow a set of rules and standards. Can be defined as:

A place of residence and work where a large number of individuals with similar situation, separated by the broader society for considerable period of time take a closed life and formally administered. These institutions are often created to take care of people who, according to popular belief, are unable and harmless. ${ }^{9}$ 
The medical perspective on old age seems to resonate directly in the operation mode and hospital-style institutions for the elderly end up purchasing. In this way, it is necessary to approach from a different perspective, one that provides an alternative to medicine about old age and look their metaphor of degeneration, a perspective that provides another wire under what is silenced in geriatric institutions.

The psychoanalyst Angela Mucida, ${ }^{10}$ aware that such conceptions of old age ignore particular issues of the subject's life, states that the understanding of the elderly must go beyond a Korp doctor, and that is such particularity that psychoanalysis will turn, when dealing with a different body than the one seen by the doctor. A body lived, crossed by the gaze of the other, with the desire and the suffering in another scene.

The basic thesis about old age in the psychoanalytic vision considers that the status of the subject is unconscious, and that this doesn't age. The attempt to define what would be old age, even if given us some indications concerning possible bodily physiological aspects or even social, do not indicate how each subject is experiencing such registration from his or hers features and personal history. ${ }^{10}$

In the context of the elderly refugee, but not restricted to it, the psychoanalysts Goldfarb ${ }^{11}$ Mucida and Abraham ${ }^{10,11}$ observed two possibilities listed on living in these institutions: the emergence of symptoms and the constant sense of nostalgia between the interns. Mucida says its clear that some symptoms are searching to inscribe singularity at the institution: the habit of collecting objects, the silence that tries to keep under some protection the traces of its desire, depressive symptoms, a hatred image of oneself. These symptoms vary as answers from what cannot be caged in each subjet. These symptoms have effects on narcissism, because nobody lives, according to the author, without certain narcissistic coverage, certain clothing that accompanies the subject, coating your body and enabling investment in subjectivity.

In this context, studies point to specifics on hospitalization between men and women in total institutions. ${ }^{12,13}$ Women, for example, can continue to play some behaviors for which were subjetivadas and "trained", as, for example, the issue of care and investing in social relationships, which may enable them to remain active and experience their personalities. The same might not happen with men who, according to Moreira ${ }^{13}$ resent more aggressively the asylum, because this implies a redefinition of their identity as men.

Finally, taking into account how much a hospitalization in a totalitarian institution asylum challenges the subjectivity of the subject that passes through this situation, it's necessary thinking that the senses, the experience of isolation and its psychic consequences (impact on mental health), and especially, if there are differences in these directions, based on gender values constituting the subjectivity of the elderly and the elderly.

\section{Method}

For the composition of this mini review, were used the platforms Lilacs, Scielo and the site of the group "Mental Health and Gender" of the Department of Clinical Psychology of the Universidade de Brasília. Our interest is to demonstrate what this group of students and teachers has contributed to studies about old age. Our mini-review question is: What do gender studies help for the compression of life in a nursing home? We use the following descriptors: mental health; gender; old age; eldery; nursing home; totalitarian institution; asylum.
As inclusion criterion, we have selected the complete articles available online and prepared by the group "Mental Health and Gender", published in Portuguese, until the year 2017. After the selection of the studies, a reading of the complete texts was made, and the main ideas and themes collected are presented below.

\section{Results and discussion}

Zanello, Henderson \& Campos (to be published) interviewed 9 men and 9 women living in a nursing home and analyze three categories common to the speech of men and women in the nursing home: "Senses of the internment camp", which concerns the intellectual and affective meaning in respect of having been hospitalized; "Experience in institution", which deals with the emotional sense of the activities (or lack thereof) in the environment asylum (which showed with full features); "What is not caged", which manifested itself in what resists the psychic crushing of the subjects within the institution. The specific topics or subcategories, which were observed in the interviews can be observed in Table 1.

Table I Frequency of themes/subcategories in the speech of the elderly and the elderly

\begin{tabular}{lll}
\hline Categories and subcategories & Women & Men \\
\hline Senses of internment & $5(9)$ & $5(9)$ \\
Feeling of abandonment & $7(9)$ & $*$ \\
Imposition of another & I (9) & $*$ \\
Only alternative & & \\
Experience in institution & $7(9)$ & $3(9)$ \\
"Hijacking of I" & $4(9)$ & $7(9)$ \\
Listen non-existent & $4(9)$ & $5(9)$ \\
Medicalization & $2(9)$ & $6(9)$ \\
Mesmidade & $2(9)$ & $2(9)$ \\
Complaints & $7(9)$ & $5(9)$ \\
Pass the time & $7(9)$ & $7(9)$ \\
Leisure & I (9) & I (9) \\
Threatening/punitive environment & $*$ & $2(9)$ \\
Repression of sexuality & $*$ & I (9) \\
Objectification of the elderly & $*$ & I (9) \\
Wellness experience & & $3(9)$ \\
What is not caged & $2(9)$ & $7(9)$ \\
Minimum exercise I & $5(9)$ & $5(9)$ \\
Will & $3(9)$ & \\
Sexuality & &
\end{tabular}

*The subcategory was not present in the speech of the respondents. ${ }^{14}$

As we can notice, the hospitalization asylum rises the question about a differentiated manner for women and men experience of suffering. ${ }^{14}$ The questioning about the senses of internment pointed to speeches marked by a feeling of abandonment. In the case of men, in general, this sense presented itself subtly, rationalized or denied. At women's side, they found, in addition to these forms, the grudge of abandonment as a betrayal (it's unfair not to get loved in return) or a sacrifice (not to cause problems, accept in order to please). In this case, the relational character traits emerge for women as ideal values, ${ }^{15}$ 
which come true in the form of the family investment most of them made during life (which enhances the feeling of betrayal, by not getting back, in old age, which invested, but instead be institutionalized and abandoned), or as the maintenance of links, even though for this they need to sacrifice themselves in silence (let themselves be admitted to please and be loved).

The interviews analyzed taken showed characteristics that confirm the geriatric institution as a totalitarian institution. They found in their study a number of complaints about the default rules and standards, as they crush, in large part, the singularities. The institution promises to offer treatment, medicines, physical therapy, healthy eating, in an idea of health as a rescue of a previous state of total well-being, but, in the interviews, complaints that the rules and regulations impersonal of the nursing home that serve to maintain order and systematic operation of the institution, becoming the largest sources of unease, because ultimately prevent the exercise of the will, the longing and the desire. And yet restrictive measures or sanctions are obliged when this singularity tries to manifest.

Men and women seem to handle this "new reality" in different ways. They, after all, are able to keep an emotional investment on this, at the expense of sacrificing themselves, silencing the malaise and avoiding the conflict, through the silencing of their complaints. The secondary gain is the attention and care dispensed differentiated by the caregiver team. On the other hand, the men refuge mainly in the past, as a way of trying to maintain an identity point of their manhood. For show more clearly their complaints, they are taken as boring and end up exerting more solitary activities. ${ }^{16}$

The researchers found on these people something that resisted, something it doesn't let itself to be caged, manifested in sexuality, in desires, daydreams, us in acts. To this something psychoanalysis suggests us to call of unconscious. It is important to question that which resists in each individual as the potencial of rescue of his own subjectivity. ${ }^{17-20}$

\section{Conclusion}

The studies developed by the Mental Health and Gender group are important sources of data that can aid in the qualitative and critical analysis of future research in the area. How can we see, the institution in order to not to incur into a totalitarian institution, and to give an ethical forwarding to its doings and enable new ways of being in the world for the elderly and elderly should consider two aspects: a) the gender values that are sources of the suffering, and so offer interventions that seek a rescue of the sense of identity; b) listening to the manifestation of the subject of the unconscious, which takes form as a particularity when one tries to impose a way of life widespread and totalizing. Disregard these two aspects makes the institution a totalitarian space that disguises itself in a hospital way, kind but nayve, of offering "well-being" and "treatment" for something that is not a disease. By this imposture, reduces its services to the exercise of a power over others.

\section{Acknowledgements}

None.

\section{Conflict of interest}

The author declares no conflict of interest.

\section{Translator}

Ronan Nascimento

\section{References}

1. Groisman D. Velhice entre o normal e o patológico. História, Ciências, Saúde-Manguinhos. 2002;9(1):61-78.

2. Foucault M. O nascimento da clínica. São Paulo: Forense Universitária, 1977.

3. Laslett PA. Fresh map of life the emergence of the third age. cambridge, mass: Harvard University Press, 1989.

4. Groisman D. Asilo de velhos: passado e presente. Estudos Interdisciplinares sobre o Envelhecimento. 2016;2:67-87.

5. Camarano A, Kanso S. As instituições de longa permanência no Brasil. $R$ Bras Est Pop. 2010;27(1):233-235.

6. Khoury HT, Rêgo RC, Silva JC. Bem-estar subjetivo de idosos residentes em instituições de longa permanência. In: DVS. FALC.

7. Pavam FJ, Meneghel SN, Junges JR. Mulheres idosas enfrentando a institucionalização. Cadernos de Saúde Pública. 2008; 24(9):2187-2190.

8. Mucida A. Identificação e envelhecimento: do espelho que não se quebra e outros espelhos. Revista Kairós. 2006;5(12).

9. Goffman E. Manicômios, prisões e conventos. São Paulo: Perspectiva. 1990 .

10. Mucida A. O sujeito não envelhece: Psicanálise e velhice. Belo Horizonte, MG: Autêntica. 2004.

11. Goldfarb DC. Corpo, tempo e envelhecimento. Dissertação de Mestrado, Pontifícia Universidade Católica de Campinas, Campinas. 1977.

12. Zanello V. Bukowitz B. Loucura e cultura: Uma escuta das relações de gênero nas falas de pacientes psiquiatrizados. Revista Labrys Estudos Feministas. 27(3):238-246.

13. Moreira CF. "Fechou-se a Porta!" (?) -uma abordagem à sexualidade feminina na terceira-idade. Tese de mestrado, Faculdade de ciências sociais, Universidade nova de lisboa, Lisboa. 2005.

14. Zanello V, Henderson G, Campos L. Instituição geriátrica como uma instituição totalitária: genêro e saúde mental. Revista Mental. BarbacenaSP.

15. Zanello V, Romero AC. Vagabundo ou vagabunda: Xingamentos e relações de gênero. Revista Labrys Estudos Feministas. 2012.

16. Zanello V, Campos L, Henderson G. Saúde mental, gênero e velhice na Instituição geriátrica. Revista Psicologia: Teoria e Pesquisa. 2015;31(4):481-488.

17. Birman J. Sexualidade na Instituição Asilar. Rio de Janeiro: Edições Achiamé Ltda. 1980.

18. Peixoto CE. Sobre a institucionalização da velhice e as condições de asilamento. In: $\mathrm{M}$ Goldenberg. editor. Corpo, Envelhecimento e Felicidade. 2011;341-356.

19. Perrot M. Os silêncios do corpo da mulher. In: M Matos, R Soihet. editors. O corpo feminino em debate. 2003;13-27.

20. Zanello V. Saúde mental, gênero e dispositivos. In: Dimenstein M. editor condições de vida e saúde mental em assentamentos rurais. São Paulo: Intermeios Cultural. 